\author{
Beril Arslan \\ ERAZMUS student, Turkey \\ Professor Dragan Nikodijević, PhD* \\ Faculty of Culture and Media \\ Megatrend University \\ Belgrade
}

\title{
PUBLIC BROADCASTING IN TURKEY: TURKISH RADIO TELEVISION CORPORATION'S ROLE IN THE PUBLIC BROADCASTING
}

\begin{abstract}
Public Service Broadcasting is „Broadcasting for the public, financed by the public and controlled by the public, aimed at informing, educating and entertaining, covering the entire geographical area of the country and having the responsibility of delivering broadcast services to all parts of the country".

The concept of public service broadcasting dates back to the founding years of the British BroadcastingCorporation. This concept was put forward by the BBC's first Managing Director, John Reith. Other European countries have established public broadcasting institutions by making changes according to their subjective conditions.

Public broadcasting in Turkey is carried out by Turkish Radio and Television Corporation. TRT, which started to serve in 1964, has signed many firsts in public broadcasting since 2007; public service broadcasting is able to compete with private channels. With the newly opened thematic and different languages and dialects, television and radio channels, TRT, which has started to increase with each passing day, needs to have a structure independent of politicalpower in terms of management.This research paper focuses on the role of TRT in public broadcasting. In the first part, public broadcasting and TRT will be explained. In the second part, the duties, management style, channels and what is the TRT will be given. In the last part of Turkish Radio and Television Corporation and location will be announced in the future of public broadcasting.
\end{abstract}

Keywords: TRT, Public Broadcasting.

*_Contact: dnikodijevic@megatrend.edu.rs

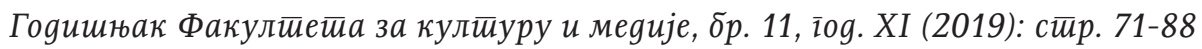




\section{Public Broadcasting}

Public Broadcasting as a Concept. When we examine the broadcasting institutions in the field of broadcasting, there are three models: public service broadcasting, commercial broadcasting and state broadcasting. However; the concept of "public broadcasting is always considered as a constantly variable concept. In this case, doesn't the concept of the public mean state-owned??

Although public broadcasting is conceptually problematic and differs in practice from country to country, it is first described by the BBC's first Managing Director, John Reith, and called "Reithian Trilogy ((Franklin, 2001: 19). And informativefunctions. In addition to adhering to the principles of universal broadcasting, public service broadcasting, reflecting national and local cultures ", focusing on the audience", broadcasting to minorities ", encouraging participation", "creating creative, original programs" and to help them discover their own abilities ", to address the minority" has a wide range of purposes (BBC, 1993: 17; Sargant, 1994: 163; Franklin, 2001: 103).

According to the results of technological developments and competitive environment, public service broadcasting has been defined as impartial broadcasting organization that brings equal information, education and entertainment to all segments of the society, provides a balanced distribution of these types of genres, pioneer in producing creative, original programs Frank (Franklin, 2001: 94-98), with accountability "(BBC, 1993: 17; Brown, 1999: 15; Brants and De Bens, 2000: 15) However, it is impossible to say that this definition will be valid for every country and every period.

History of Public Broadcasting. Curran complains that the studies that deal with media history are media-centric (mediacentric) and are written as the history of media technology determinism (Curran, 2002: 135). In this study, although there is no attempt to write a history of media, it is said that technological developments play an important role, although the impact of social and political developments is not overlooked when the development of public service broadcasting is taken into consideration.

First, the invention of radio and then television was the result of developments in the age of enlightenment and industrial revolution in the 18th and 19th centuries. With the invention of these tools, 'the public service' understanding emerged from the need for regulation in use. Following the Industrial Revolution, the understanding of the "social state emerged from the clash between the organized demands of the proliferation of workers in the cities and the liberal philosophy developed by Smith. During this period, the state, "redistribution of", "the expansion of welfare programs", "development of education" the idea that a tool is adopted (Giddens, 2000: 223). At the root of public service broadcasting, there is the idea of the state's under-

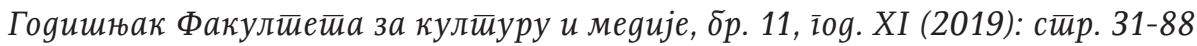


standing of guaranteeing the provision of certain social services to everyone without class distinction, and therefore the limited frequency distribution in the equality within the reach of all. In broadcasting, it was perceived as a service that should be provided to everyone, such as health, social assistance and education, and it was assumed that private enterprise could not distribute this service equally.

Image analysis tube developed by US engineer Vladimir Kosma Zworykin of Russian origin started the transition to modern TV broadcasting, the first television broadcasts started in 1930, Germany in 1935, England in 1936, and regular television in the USA in 1941 publications. II. After a short pause during World War II, television broadcasting developed rapidly after the end of the war. The invention of television has raised the problem of how to use this device, a legal regulation was needed and the regulations for radio in European countries have also been a guide for television (Pekman, 1997: 5). In the 19th century, editing work began with telegraph; the first legal arrangements were made with radio and then television (Papathanassopoulos, 1990: 113).

The Labour Party, which has been in power since 1923, opposes the granting of a public service monopoly to private organizations. At the request of the government, the Crawford Commission was established in 1925 to determine the way radio works. The report of this commission opposes the release of the radio to a private company for profit, but does not accept an understanding that the state will operate directly. The report proposes the formation of a board of directors that is in line with national interests and organizes it as a public institution. Thus, the British Broadcasting Company was transferred to the British Broadcasting Corporation in 1927 with its entire staff (Kaya, 1985: 123124).

Although the US system is commercial and programs are tailored to consumer wishes, PBS (Public Broadcasting Service) for public interests has an important place in broadcasting as well as large television networks. In the US, 348 public television stations in 50 states are broadcasting. These publications do not aim for profit and do not include advertising. In the US broadcasting system, the concept of "public, means broadcasting for the benefit of society in order to balance commercial publications. Service is not owned or controlled by the state. Despite the widespread commercial understanding in the United States, this system arose from a need for a lack of commercial broadcasting. In the early 1950s, as a result of the inconvenience of commercial broadcasting, educational television sets were established throughout the states and at universities. These stations do not broadcast ads, they only prepare cultural programs. A law enacted in 1967 decided to support these non-commercial stations by the state. In 1969, the Public Broadcasting Service was established. 
In this country, the use of frequencies was initially released, the application created great chaos due to the limited frequencies, and in 1927 the Federal Radio Commission was established to regulate this complexity (Pekman, 1997: 9).

\section{Turkish Radio Television Corporation (TRT)}

Turkish Radio Television Corporation, the publisher is the sole authority tasked with doing public broadcasting in Turkey. It is essential that TRT is autonomous and its broadcasts are impartial.

\section{History of TRT}

Turkish Radio Television Corporation (TRT), in order to perform on behalf of the state radio and television broadcasts of May 1, 1964, were established under private law. With the constitutional amendments in 1972, the institution was defined as a "neutral state economic institution.

In line with the provisions of the 1982 Constitution, Turkish Radio and Television Law was revised in 1984. With the amendment of Article 133 of the Constitution in 1993, private radio and television broadcasts were released and TRT regained its autonomy. Today, TRT serves as a public service broadcaster, whose autonomy and impartiality are stipulated in the Constitution and broadcast on radio, television and all media.

Radio broadcasts in Turkey, the first time Turkey has started depending Inc. Cordless Phone. It is known that Ankara Radio made its first broadcasts in 1928 after Istanbul Radio started broadcasting on May 6, 1927. Later, Ankara and Istanbul Radios were transferred to PTT on September 8, 1936. During World War II, the radios were connected to the newly established General Directorate of Press (General Directorate of Press and Tourism / Information). Izmir Radio, which started broadcasting in 1950 under the Izmir Municipality, has continued its broadcasts under the General Directorate of the Press since 1953. After 1960, Provincial Radio was established in eight provinces. After 1964, the radio broadcasting continued under the umbrella of TRT and became more appealing to a wider audience with the strengthening of its transmitters. In 1974, TRT-1, TRT-2 and TRT-3 radio stations were put into service by combining the central and regional radios of TRT.

Turkey's first television broadcast of the trial on January 31, 1968 in Mithatpasha Studio in Ankara MahmutTali Predicting started with an opening speech; the trial publications started three times a week, three hours a week and increased to four days a week. Izmir Television in 1970 and Istanbul Television in 1971 began to operate.

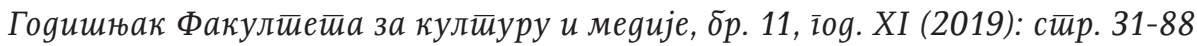


In 1974, television broadcasts took place every day of the week, with $55 \%$ (19 million) of the country's population and $28 \%$ of the country's surface area. At a time when developed rapidly in the world of communications and television broadcasting Turkey it is no longer indifferent to this process. In this process, it is seen that the new television channels in TRT have been put into service rapidly with the demand of the society and the broadcasting hours have been increased. In 1984, a full-colour publication was started.

Published in 1986, starting the second television channel TRT-2 was delivered via satellite to the whole of Turkey in 1987 with the TRT-1. With the introduction of TRT-3 and GAP-TV in 1989, TRT's number of television channels increased to 4. In 1990, TRT4 for education-oriented TRT4 and TRT-INT for Turkish workers living in Europe, TRT-EURASIA channel which includes programs for Caucasus and Central Asia in 1993, and TBMM TV in 1995 began broadcasting. As the 2000s approached, it is seen that internet networks and internet usage spread rapidly in the world. In 1999, the TRT website was launched at www.trt.net.tr and reached many points.

Children's channels fulfil an important responsibility for language and mind development. 1 In November 2008, domestic children's channel TRT Turkey's first and only began to be a feature of children's broadcasting.

On 1 January 2009, the channel broadcasting in different languages and dialects, TRT-6 (TRT Kurd) went into service. On 20 November 2008, www. trt-world.com ranked 5th in the world among broadcasters in the new media service environment with news broadcasts in 31 languages. TRT Avaz started broadcasting on March 21, 2009 in order to preserve the unity of language and culture in the wide geography where Turkish is spoken.

TRT Turk started broadcasting on May 8, 2009 as an international Turkish news and culture channel. TRT ANADOLU, which started to serve in the same year, was foreseen as a channel to be broadcasted jointly by TRT and the Union of Local and Regional Television, and then TRT Religious was delivered to the audience with the same frequency. TRT Music, which was launched on November 16, 2009, contributes to the reach of Turkish music and culture to a wide audience.

Launched on 17 October 2009 Turkey on TRT Documentary Channel; It aims to introduce the world in five different languages with English, German, French, Russian and Turkish. In 2009, Radio 6, TRT Tune, TRT Ankara Kent Radio, TRT Folk and TRT Europe FM radios started broadcasting.

As a result of the cooperation of TRT with Euronews, Euronews news channel started broadcasting in January 2010 in Turkish as the 9th Language. This situation allowed Turkish to reach the masses in a wide geography and provided an important source of listening and monitoring especially for foreigners who want to learn Turkish.

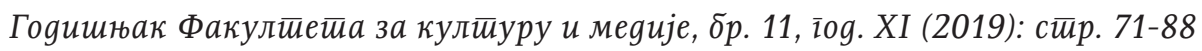


TRT HD channel, which broadcasts HD, which is the highest point in broadcasting quality, mainly includes sports, documentaries and cinema. TRT Sports, which was launched in August 2010, carries all national and international sports competitions and organizations to the screen live or from the band, while giving importance to every branch of the sport.

The TRT School, which was launched in January 2011, is a technology and education channel with educational and cultural programs for various age groups.

TRT Publishing History Museum, which was opened on 10.12.2012, took a journey of 20 provinces with a museum wagon prepared on the occasion of the 50th anniversary of TRT's establishment on 31.01.2014. In 18.05.2015 started its test broadcasts, English broadcaster TRT World, through publication on 29.10.2015, it has been a major worldwide brand of Turkey. 10/04/2015 Turkey and the first time a football match in Europe (Fenerbahçe-Ajax) was published in the TRT 4K channel.

At the 52nd ABU General Assembly held in Istanbul in 2015, TRT General Manager was unanimously elected as the Vice President of ABU and in the same year, Astana-Kazakhstan, London-England and Skopje-Macedonia representations were opened. In 2016, TRT became a member of the board of directors and vice president of the Mediterranean Permanent Audio-Visual Conference (COPEAM). Radiovision, A World Music and a refereed journal, TRT Academy Magazines were added to TeleV ZYON Magazine, which has been published since 1987. TRT today, 14 television channels, 14 radio channels, and 41 languages trt.net.t prepared www.trtvotworld.co website, the magazine is published five printed by Turkey and the world.

TRT, acting with the responsibility of public broadcasting; culture of our country, while providing substantial support to the arts and education, to address immediate and reliable journalism, in its international broadcasts by the power of Turkey in different languages, voice has continued to reflect the entire world.

\section{Turkish Radio Television Corporation}

The Duties of TRT. TRT, which has certain broadcasting principles, is responsible for performing certain duties along with these principles. According to Article 9 of Law No. 2954 on Turkey Radio and Television of Turkish Radio and Television Corporation some tasks are as follows:

a) To establish the necessary units for the purpose of news gathering and program broadcasting and production for radio and television broadcasts, 
b) within the borders of Turkey, which broadcasts local, regional, national radio and television agreements with institutions and organizations, to sign the agreement and protocols; and to sign agreements, agreements and protocols with international radio and television institutions and organizations when necessary with the approval of the Prime Ministry,

c) To be made domestically; news, culture, science, art, educational, entertainment, and similar species, enlightening and entertaining nature with all kinds of publications: Ataturk's principles and reforms of rooting on, foreseeing the emergence of contemporary civilization level of the Republic of Turkey to help the realization of national goals. To help preserve and strengthen the democratic, secular and social state of law, which respects human rights and is based on Atatürk Nationalism, within the understanding of national solidarity and justice, the existence and independence of the state, the indivisible integrity of the country and nation, the peace of the society. To help the development of national education and national culture.To help the public be formed freely and in a healthy way in accordance with the constitutional principles.

d) With publications to be made abroad; It is introduced in all areas of the state and Turkish citizens who are abroad help maintain relations with the Republic of Turkey.

\section{Management of TRT}

According to the Law no. 359, TRT has two main bodies: the Board of Directors, which is the highest decision and management body, and the General Directorate, which enforces the decisions. There are also administrative units such as Advisory Boards, Political Publications Referee Boards.

Board of Directors: The term of office of the members constituting the Board is five years according to Article 4 of the Law no. 359 and they cannot be suspended in any way during this period. Considering the impartiality and autonomous structure, the members were selected by various units and they were taken care not to be members of political parties.

General Manager: The General Manager is the person who represents the institution and is responsible for the publication. Appointment is made by the decisions of the Council of Ministers and the decisions of the Board of Directors are carried out under the supervision of. This assignment, which took place by political power, "impartiality" and "autonomy" do not agree with the principle of the question comes to mind.In order to prevent this negativity, it is envisaged that the General Manager shall be subjected to the Board of

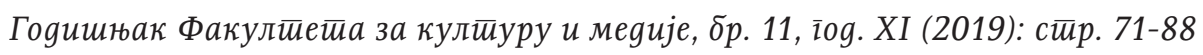


Directors, which has an autonomous structure in exercising decisions and powers, and shall work impartially.

However, in the formation of the Board of Directors, which is the highest decision-making and governing body, there is a contradiction that the General Manager, who is the representative of the institution, can be appointed and dismissed by the government. Reasons for the dismissal of the General Manager; public order, foreign relations and national security. For any of these reasons, the government is required to make a written decision of the Board of Directors. However, regardless of the decision taken, the last word belongs to the Council of Ministers. According to the TRT law, there are three Assistant General Managers: Deputy General Manager, Deputy General Manager, News and Program Assistant, General Manager Technical Assistant.

The appointments of these assistants are made by the Board of Directors upon the proposal of the General Manager and their dismissal is done according to the procedure in their appointment.

Advisory Boards: Article 10 of Law No. 59 states that The Board of Directors may establish various boards to consult on matters related to radio and television services. Personnel of the institution may also participate in the Advisory Boards but cannot vote. The purpose of the participation of corporate staff in these boards is to provide the principle of transparency in management. After the establishment of TRT, various regional advisory boards were convened. The task of the Boards is to assist in the identification and elimination of regional needs and to give opinions and suggestions to the General Manager on these issues. In this way, it is determined what the various segments of society think about the publications, what their desires are, and thus, the institution gains a democratic process.

Arbitration Committee for Political Publications: This committee is established in accordance with Article 12 of the Law. Its members are not members of political parties. The Political Publications Arbitration Committee may also convene upon the call of the General Manager. Its task is to examine the application concerning the broadcast of political parties and give the right answer needed (Turkey Radio and Television Corporation Law No. 359, m.10).

\section{TRT Channels - Television}

TRT-1: It is a family channel. Turkey's most watched television channel TRT-1 channel format in the family; education, culture, drama, music, entertainment, sports and news broadcasts on where the program will appeal to all of Turkey.

TRT-WORLD: It is a news channel that broadcasts entirely in English to the world.

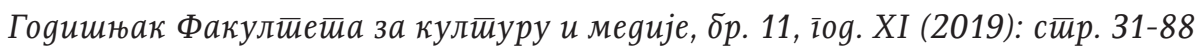


TRT-NEWS: Current news, politics, analysis, discussion, sports, documentaries, culture and art broadcasting news channel.

TRT-SPORTS: TRT Sports, which was launched in August 2010, carries all national and international sports competitions and organizations to the screen of live or band and gives importance to every branch of the sport.

TRT-AVAZ: Launched in March 2009, Uzbekistan, Kazakhstan, Kyrgyzstan, Turkmenistan, Azerbaijan, Bosnia and Herzegovina, including Albania and Turkey from 8 countries and country-specific in 8 languages, living in a region extending to the Far East to the Balkans Turkish broadcasting to the world channel, Turkey and other Turkish Republics between language and thought establishes unity. AVAZ, which means VOICE in many Turkish dialects, addresses the geography of approximately 250 million people in 27 countries and 13 mukhtars from the Middle East to the Caucasus as the common voice of the Turkish Republics.

TRT-CHILD: The channel, which meets all the needs of contemporary Turkish children from animation to music, from news to sports, aims to contribute to raising healthy generations physically, mentally, spiritually and morally. TRT Child, which aims to support and guide the development of children with the principle of quality, contemporary and responsible publishing in universal pedagogical norms, aims to promote the Turkish language and culture correctly, to educate and raise children's awareness by playing, having fun.

TRT-DOCUMENTARY: Turkey English, German, French, introducing the world in five different languages with Russian and Turkish TRT Documentary Channel, history, society, nature, environment, sports, culture, arts, science, publications, documentary programs in the field of technology. The channel, which transmits the past to the future and traces nature, began broadcasting on October 17, 2009.

TRT-MUSIC: Turkey and the channel that connects the world's music, competition programs, music documentaries, concerts, programs generations, Top 10 and live programs are published. On 16 November 2009 the channel began broadcasting, Turkish Folk Music and Art in Turkey although mainly with domestic and foreign music and music bring to the screen the difference in the world with TRT.

TRT-ARAB: Turkey's international and especially to contribute positively to the relations with the countries of the region in order to set out the TRT Arab common language of Turkey and the Arab world, public display, in order to common sense, addressing audiences of all ages, children, youth, women, health was launched in April 2010 with a rich content of economy, drama, documentary, sports, music, news, culture-art, religion-morality and entertainment programs. Arabic-speaking, 22 Arab countries and for the Arabicspeaking channel broadcasting aims to strengthen ties between Arab countries and Turkey with a population of 350 million. 
TRT-TURK: Turkish broadcasting channels mainly in the world, with the program to introduce the Turkish people, Turkey, news, culture and arts publication, the look of our citizens and compatriots living abroad Turkey and rupture with Turkey Culture, support issues, aims to be a partner of sadness and joy.

TRT-Kurd: TRT channel broadcasting in Kurdish in Turkey with international contribute positively to the relations with international and regional countries in particular. The Kurdish Family Channel TRT-Kurd, which aimed at the unity and integrity of our country, appealing to audiences of all ages in contemporary norms, began broadcasting in January 2009.

TRT-SCHOOL: The TRT School, which was launched in January 2011, broadcasts educational and cultural programs prepared by TRT for various age groups, short spots and various programs for young people.

TRT-3: TBMM TV and TRT Sports channel, where the Parliament broadcasts are broadcasted, take place on the TRT 3 screen with time sharing.

\section{TRT Channels - Radio}

TRT RADIO 1: It is a radio channel broadcasting in education, culture and news since 1927.

TRT FM: It is a radio channel that broadcasts music with the understanding of live and dynamic broadcasting.

TRT RADIO 3: This is a radio channel that broadcasts classical music.

TRT TUNE: This is the radio channel that broadcasts Turkish Art Music.

TRT FOLK: It is a radio channel that broadcasts folk songs such as Voices from the Yurt, folk poets and amateur communities.

TRT MY HOMELAND FM: It is a radio channel that broadcasts daily and current issues.

TRT TSR: Various domestic and foreign issues, reflecting the views of Turkey; which contribute to the promotion of our country, „the Voice of Turkey" (TSR) is a radio station which broadcasts in 34 languages.

TRT ANTALYA RADIO: It is a radio channel that broadcasts reflecting the colours, music, culture and traditions of the Mediterranean since 1962.

TRT ÇUKUROVA RADIO: It is a radio channel that broadcasts reflecting the smell, life and local values of the Taurus Mountains since 1968.

TRT GAP DIYARBAKIR RADIO: It is a radio channel that broadcasts reflecting South-eastern Anatolian culture, the voice of the region and folklore since 1964.

TRT TRABZON RADIO: Since 1968, with green, blue; is a radio channel that broadcasts reflecting the Black Sea with its overalls and kemence.

TRT ERZURUM RADIO: It is a radio channel that broadcasts reflecting Eastern Anatolia with its folk songs and folklore since 1960. 
TRT RADIO KURD: It is a Kurdish radio channel that aims to contribute to the unity and integrity of our country and those appeals to listeners of all ages with its contemporary understanding of broadcasting. Radio 6, which began broadcasting on May 1, 2009, delivers its voice to the South-eastern Anatolia Region. While strengthening the bond between the people of the region with Turkey's government has also had a positive effect on international relations.

TRT RADIO NEWS: It is a radio channel that broadcasts news, news program, weather and road conditions, cultural and artistic activities for all segments of the country.

\section{Internet}

TRT.net.tr: TRT, which defines the internet as a new broadcasting medium that provides data and information to the public, shapes its broadcasts in this direction and has carried the broadcast quality that it has sustained for years with its modern studio facilities. Internet users who prefer TRT because they find it to be accurate, fast and reliable are now finding more satisfying content at www.trt.net.tr. The TRT website, which has been reorganized with a contemporary design, offers high quality service in every field of broadcasting by providing an internet broadcast that can reach the broad masses with the most comprehensive content in internet journalism with its strong technical infrastructure. TRT's web site enables readers to make effective use of the internet with its renewed face and content.

While the main page of the site offers different access points for news, the links "Television", "Radio", "News", "Sports", "Finance" and "Languages" provide access to the portals.

With the Podcast system, the user can watch and listen to the television or radio program by downloading the desired TV or radio program, while the streaming system enables the users to access sounds and images without downloading data to the computer and simultaneously watch 15,000 videos by different viewers.

Another important feature of the new website is that it is accessible from different devices and different browsers. The internet site can be accessed from mobile phones and other mobile devices (PDAs) with media players. The content can be accessed with different internet browsers and dynamic content presentation can be realized by compressing content according to the access speed of the devices.

TRT Vote: radio broadcasts abroad for Turkish Radio Television Corporation, is carried by the Voice of Turkey. Broadcasts, short wave transmitters, satellite and bring the whole world via the Internet Turkey's volume, while 
maintaining its traditional radio broadcasting, by staying away from too rapid technological changes affecting the publishing world, strong technical infrastructure and website revamped with rich Internet broadcasts in 35 languages, the user of the service offers. It trt-vot.co Launched On 20 November 2008 out of today with news broadcasts in 35 languages and dialects, followers of the world and Turkey's agenda are sent to the internet.

In TRT-Vot, German, Arabic, Albanian, Azerbaijani Turkish, Bosnian, Bulgarian, Chinese, Dari, Persian, French, Georgian, Croatian, English, Spanish, Italian, Kazakh, Kyrgyz, Hungarian, Macedonian, Uzbek, Pashto, Romanian Russian, Serbian, Tatar, Turkmen, Urdu, Uighur, Greek and Armenian.

Hot developments about the region and the whole world, published on www.trt-vot.com, are presented to the world public with a comprehensive, unbiased and accurate content including the opinions of experts. Emphasis is primarily on news content for each language on regional news, news ranking second in the world located in the news, while Turkey after news of the developments are discussed on the agenda.

Turkish Radio Television Corporation are engaged in Turkey's public broadcasting television station. TRT broadcasts on television, radio and internet.

On TV: A lot of the broadcast medium where the national and regional television channels in Turkey and the world „accurate and unbiased" news that the TRT, education, culture, documentary, drama, sports, music and entertainment broadcast of Anatolia, 99\% and cross-border and broadcasts for audiences of all age groups.

TRT broadcasts; aims to provide accurate, objective, understandable and immediate news to audiences of various ages, professions, education and culture levels, to contribute to educational and cultural developments, to educate them while entertaining and to ensure the integration of national culture in its most common form.

On Radio: TRT Radios 5 national, 5 regional, 3 local and 5 international radio channels, public broadcasting responsibility, impartial and principled broadcasting approach, accurate and beautiful Turkish, news, information, education, culture, music, entertainment content; it addresses every corner of the country and every segment of society.

On Internet: The news portal, which allows live viewing of the news, takes place with the latest news, images, photos and comments. From the Portal; „Turkey, World, Business, Sports, Health, Environment, together with the Culture and Arts" category, the summary of the world press, news programs on the opportunity to re-watch that and recently added video news podcast app can also be reached. 


\section{TRT's Role in Public Broadcasting}

Turkish Radio Television Corporation, which is Turkey's public broadcasting and public broadcasting mission undertaken by a single institution. Therefore, it has an important place in the public broadcasting sector. TRT broadcasts a wide range of radio and television broadcasts both in Turkey and abroad and continues its broadcasts through 14 channels. From the point of view of the TRT in terms of public broadcasting from the past to the present; it is observed that the TRT Institution experienced a period of sluggishness in terms of broadcasting reflex of the previous periods and survived this situation. Today TRT is not insensitive to developments and innovations.

Since 2007, TRT Authority has opened new channels and increased the number of channels; continues to broadcast on a wide area with 14 TV channels and 14 radio channels.

With the concept of thematic broadcasting, news, children, education, music, broadcasting through channels such as documentaries; the understanding of uniform, ordinary and general publishing was broken; the needs of new audiences for different tastes and preferences were responded to. In addition, the opening of channels broadcasting in different dialects is also a first in the history of public broadcasting in TRT.

On the other hand, a competitive element was introduced and it was aimed to establish the understanding that each channel coordinator had to follow the developments, technology and broadcasting in the world for the success of the channel for which it was responsible. With the steps taken and channels opened, it is observed that TRT has made an effort in the field of public broadcasting, which can reach all segments and reach all segments. Looking at these results it is seen that Turkish Radio and Television Corporation have a very important place in terms of what public broadcasting sector.

Public broadcasting is an important debate in many countries. Particularly with the 21 st century, the shares allocated by the states for public broadcasting and the expenditures made for public broadcasting became more prominent. When it comes to old media, such as television and radio, even consumed by the private sector, we can question the meaning of these investments at length.

Turkish Radio Television Corporation is one of the organizations engaged in public broadcasting. TRT is obliged to make a payment to the channels, broadcasts and the people within it. For this, his publications should be loved and watched by the audience. However, this situation has not been going as desired recently. TRT is a public broadcasting organization, but it has recently been under the influence of the state. This situation is not very welcome for TRT which is a public broadcasting organization. Of course, the solution that 
can be proposed is not to close or completely privatize the TRT. Instead, its national operation can be made narrower, but more quality and innovative, and its global operation broader, but based on more universal journalistic principles and a certain competitive understanding.

TRT is a public organization and will always remain a public organization. So in this case there is a future of Turkish Radio Television Corporation. It is possible for this future to be bright with the regulations to be made in broadcasting policies and the influence of the state.

\section{Conclusion}

In its simplest form, the basics of public broadcasting, which corresponds to broadcasting to inform, educate and entertain, was laid by the BBC's first Managing Director, Sir John Reith. Public broadcasting is generally defined as a broadcasting organization, organized as a public institution, offering balanced distribution of program types according to the functions of reporting, educating and entertaining in broadcasts accessible to everyone in the society on an equal basis and observing impartiality and balance in political issues.

Turkish Radio Television Corporation to Turkey in the year 1964 the public broadcasting sector (TRT) to enter. TRT public broadcasting adventure started with a single channel broadcast today, 14 television channels, 14 radio channels, web sites trt.net.t and www.trtvotworld.co prepared in 41 languages, 5 magazines printed with Turkey and is broadcast to the world.

This research papers on the role of public broadcasting in Turkish Radio Television Corporation was investigated. In the first part of what public broadcasting and Turkish Radio and Television Corporation and explained that they are given information about the date. In the second part, the duties of TRT, how they are managed and information about television, radio channels and web pages are given. At the same time, what TRT does is explained. In the third part; the role of TRT in public broadcasting has been explained and discussed about the future of TRT.

Turkish Radio Television Corporation is Turkey's only public broadcasting organization. It has made a name for itself with its publications since its establishment. TRT, acting with the responsibility of public broadcasting; culture of our country, while providing substantial support to the arts and education, to address immediate and reliable journalism, Turkey's power with his international publications in different languages, will continue to reflect the voice of the whole world. 


\section{References}

\section{A. Books}

[1] Turkey Radio and Television Corporation Law No. 359.

[2] BBC,(1993), Responding to the Green Paper, W1A 1AA, BBC, London: Published by the British Broadcasting Corporation, Broadcasting House

[3] Brants, K., De Bens, E.(2000),The Status of Broadcasting in Europe, Television Across Europe, (Ed. Jan Vieten, Graham Murdock and Peter Dahlgren), London: Sage Publication

[4] Brown, D.(1999),FT Focus on the BBC, FT Media Maple House, London

[5] Curran, J.(1997),Media and Democracy: Revaluation, Media Culture Politics, (Ed. and Translation Süleymanİrvan), Ark Books, Ankara

[6] Franklin, B.(2001),British Television Policy: A Reader, Routledge, London

[7] Giddens, A.(2000), Contemporary Criticism of Historical Materialism, (Translation ÜmitTatlıcan), Pradigma, Istanbul

[8] Kaya, A.R.(1985),Kitlė̇letişimSistemleri, TeoriYayıncılık, Ankara, 1985

[9] Papathanassopoulos, S.(1990),Public Service Broadcasting and Deregulatory Pressures in Europe, Journal of Studies in International Education, 16, 113120, http://Jsi.sagepub.com (Accessed on December 20, 2019)

[10] Pekman, C.(1997),TelevizyondaÖzelleşme: Avrupa'daYayıncıllŭınDeğişimSür eci, BetaBasım-YayımDağıtım, Istanbul

[11] Sargant, N.(1994),The Structure of Television in the UK, Television and the Viewer Interest: Exploration in the Responsiveness of European Broadcasters, (Ed. Jeremy Mitchell and Jay G. Blumler with Philippe Mounier and AnjaBundschuh), John Libbey, London

\section{B: Web}

[12] Anon, KURUMSAL. TRT. Available at: https://www.trt.net.tr/Kurumsal/ Tarihce.aspx [AccessedDecember 29, 2019].

[13] Anon, KURUMSAL. TRT. Available at: https://www.trt.net.tr/Kurumsal/ Gorevlerimiz.aspx [AccessedDecember 29, 2019].

[14] Anon,KURUMSAL. TRT.Availableat:https://www.trt.net.tr/Kurumsal/ TelevizyonTanitim.aspx [AccessedDecember 29, 2019].

[15] Anon, KURUMSAL. TRT. Available at: https://www.trt.net.tr/Kurumsal/ Radyotanitim.aspx [AccessedDecember 29, 2019].

[16] Anon,KURUMSAL. TRT.net.trTanitım.Availableat:https://www.trt.net.tr/ Kurumsal/TrtnetTanitim.aspx [AccessedDecember 29, 2019].

[17] Anon,KURUMSAL. TRTVotTanıtım.Availableat:https://www.trt.net.tr/ Kurumsal/TrtvotTanitim.aspx [AccessedDecember 29, 2019]. 
[18] Anon,KURUMSAL. TRT.Available at: https://www.trt.net.tr/Kurumsal/ YayinIlkelerimiz.aspx [AccessedDecember 29, 2019].

\section{Thesis}

[19] Y1ldız E.,(2012), Kamu Yayıncılı̆̆ı ve TRT, Selçuk Üniversitesi, Sosyal Bilimler Enstitüsü, Konya

[20] Eren E., (2008), KAMU YAYINCILIĞI VE BİR KİTLE İLETIŞ่İM KURUMU OLARAK TÜRKIYYE RADYO TELEVIZZYON KURUMU (TRT), Mimar Sinan Güzel Sanatlar Üniversitesi, Sosyal Bilimler Enstitüsü, İstanbul 


\section{Берил Арслан \\ ЕРАЗМУС сйуgенй, Турска \\ Проф. др Драган Никодијевић \\ Факулиетеи за кулйуру и меgије

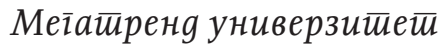 \\ Беоіраg \\ ЈАВНА РТВ У ТУРСКОЈ: УЛОГА ТУРСКЕ РАДИО ТЕЛЕВИЗИЈЕ У ЈАВНОЈ РАДИО-ДИФУЗИЈИ}

Сажейак: Јавни сервис за раяиоgифузију је "емитер за јавности, финансиран о с сиране јавности у ииљу информисања, еgукаиије и забаве, иокрива иео іеоірафски иростиор зенље и има оgі̄оворности исиоруке емийоваюа услуіе свим деловима земље." Јавно емитоване у Турксој сировоgи корйораиија Турске раяио-иеелевизије ТРТ, која је йочела са раgом 1964, а

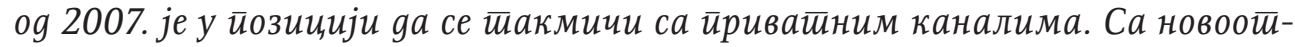

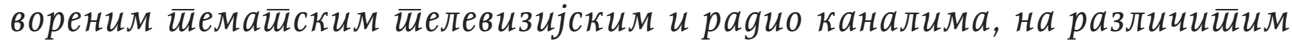
језицима и gијалекитима, уз свакояневно иовећање, ТРТ мора gа има сой-

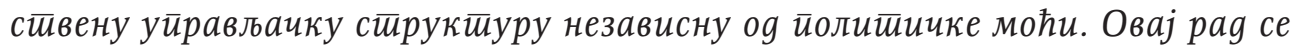

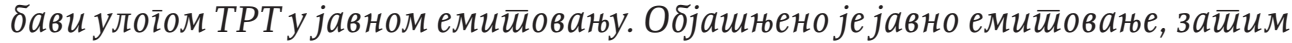

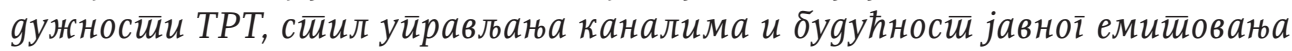
иелевизијскоі и раяио емитововь у Турској.

Кључне речи: ТРТ, јавно емитовање 